\title{
CHANGES IN VOLATILE COMPOUNDS AND OIL QUALITY WITH THE METHOD OF OLIVE TREE PROPAGATION AND SALINE WATER IRRIGATION
}

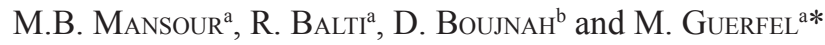 \\ anstitut Supérieur de Biologie Appliquée de Medenine, Université de Gabes, B.P 522, 4100 Medenine. Tunisia \\ 'Institut de l'Olivier, Station de Sousse, Rue Ibn Khaldoun, B.P. 40, 4061 Sousse. Tunisia
}

(Received: 9 January 2013; accepted: 29 March 2013)

The main goal of this study was to investigate the effects of moderate saline water irrigation on the composition and
quality of olive oil of the "Chemlali" olive cultivar in comparison to a control plot grown under rain-fed conditions
from two methods of olive tree propagation (suckers and cuttings). The antioxidant compounds, oxidative stability
and volatile compounds of virgin olive oil samples were determined and reported. The irrigation did not affect free
acidity and peroxide value and specific ultraviolet absorbance $\left(\mathrm{K}_{232}, \mathrm{~K}_{270}\right)$. Whereas, fatty acid composition, oxidative
stability, total phenol, total chlorophyll and carotenoid contents were affected by irrigation. Rain-fed virgin olive oils
showed a statistically significant higher content of oleic and linoleic acids. However, olive oil samples obtained from
fruit of irrigated trees from suckers had a higher content of $(E)-2$ hexenal $(67.2 \%)$ and a higher content of total
phenols $\left(860 \mathrm{mg} \mathrm{kg}^{-1}\right)$. Interestingly, more stable oil was obtained from moderate saline water irrigated trees from
suckers compared to olives from cuttings.
Keywords: cuttings, fatty acids, moderate saline water irrigation, oxidative stability, suckers, virgin olive oils, volatile compounds

The chemical and organoleptic characteristics of olive oil depend on several factors (SALVADOR et al., 2001). According to APARICIO and LunA (2002), these factors are clustered into four main groups: environmental (soil, climate), cultivation (ripeness, harvesting), technological (fruit storage, extraction procedure), and agronomic factors (fertilisation, irrigation). Among these factors irrigation is a major factor of olive oil quality (GomEz-Rico et al., 2007).

Tunisia is next to Spain, Italy and Greece in the world olive oil sector regarding the number of trees and olive oil production; Tunisia produced 144500 tonnes per year between 2000 and 2006.

Many studies have focused on the effect of irrigation with fresh or saline water on olive oil composition. Patumi and co-workers (2002) found that olive oil composition did not change with irrigation, except for the total phenols, which decreased. WIESMAN and coworkers (2004) reported that irrigation with saline water did not affect the olive oil basic quality parameters, such as free acidity, peroxide value, and fatty acids composition. However, the saline treatments increased the level of certain antioxidant components (polyphenols and vitamin E). BouAziz (1990) did not find any changes in the fatty acid composition of the oil when olive trees were irrigated for 12 years with brackish water.

The conventional method of olive tree propagation in Tunisia is based on vegetative multiplication using cuttings, grafting, or suckers. These methods have been frequently used for the propagation of some highly valued cultivars, particularly the Chemlali cultivar.

\footnotetext{
* To whom correspondence should be addressed.

Phone: +216 75633 919; fax: +21675 633918; e-mail: Guerfel_mk@yahoo.fr
} 
"Chemlali" is the main cultivated Tunisian cultivar of olive. This cultivar covers an area of 1334 ha, mainly located in the north and in the centre of Tunisia, and accounts for $80 \%$ of the national oil production (BACCOURI et al., 2007).

Traditionally, olive trees have been cultivated under rain-fed conditions. In recent decades, the olive plantation has been extended to irrigated lands. However, in arid and semiarid regions such as those in Tunisia, the limited water availability and the increased need for good water quality for urban use restrict the use of fresh water for irrigation. Therefore, large quantities of marginal water, such as saline water, are used for olive tree irrigation [33\% of irrigated lands are saline water irrigated (16 $000 \mathrm{ha})$ ]. This is the first evaluation of the effects of saline irrigation on the chemical composition of Chemlali virgin olive oils in relation to the method used for the olive tree propagation (cuttings, suckers). The aim of this work was to investigate the effects of moderate saline water on the quality of virgin olive oils of Chemlali trees from cuttings and suckers based on the study of major (fatty acids) and minor compounds (phenols, chlorophylls, carotenoids) as well as on the oxidative stability.

\section{Materials and methods}

\subsection{Oil sample extraction}

Olive oil samples were obtained from fruit of the main Tunisian olive cultivar, Chemlali, which were picked by hand at the same stage of maturity from three trees during the crop season 2009/2010 (October) in a 4- ha olive orchard located in Souassi center of Tunisia $\left(35^{\circ} .49^{\prime} \mathrm{N}, 10^{\circ} .30^{\prime} \mathrm{E}\right)$. Two treatments were used: rain-fed trees and trees irrigated by moderate saline water (MSW) with continuous drip system. Both treatments had the same soil texture. Each treatment block consisted of a row of six trees. Irrigation with MSW was applied in spring (April-May) and in an autumnal period (October-December). The $\mathrm{pH}$ of the MSW was 7.6, falling within the $\mathrm{pH}$ range 6-9 appropriate for irrigation reuse (RATTAN et al., 2005). Electrical conductivity (EC) was $4.3 \mathrm{dS} \mathrm{m}^{-1}$, indicating a moderate level of salinity (WIESMAN et al., 2004). Climatic conditions of the experimental site were obtained from a meteorological station installed within the experimental orchard. Averages of rainfall and air temperature were recorded. Olive trees were trees planted in 1988 and were subjected to identical fertilisation regime and to all common olive cultivation practices. The same laboratory mill was used to prepare the olive oil samples. Only healthy fruit, without any kind of infection or physical damage, were processed in triplicate from each treatment. After harvesting, fresh olives $(1.5-2.0 \mathrm{~kg})$ were washed and deleafed, crushed with a hammer crusher, the paste was mixed at $25^{\circ} \mathrm{C}$ for $30 \mathrm{~min}$, centrifuged without addition of warm water (oil produced from each extraction was $200-250 \mathrm{ml} \mathrm{kg}^{-1}$ ), transferred into dark glass bottles, and stored (one week) in the dark at $4{ }^{\circ} \mathrm{C}$ until analysis.

\subsection{Determination of oil quality parameters}

Free acidity, expressed as percent of oleic acid; peroxide value, given as milliequivalents of active oxygen per kilogram of oil $\left(\right.$ meq $\left._{2} \mathrm{~kg}^{-1}\right)$; and UV absorption characteristics $\left(\mathrm{K}_{232}\right.$ and $\mathrm{K}_{270}$ ) were determined according to the analytical methods described in the European Union Commission Regulations. 


\subsection{Fatty acid composition}

The fatty acids were converted to fatty acid methyl esters before analysis by shaking a solution of $0.2 \mathrm{~g}$ oil and $3 \mathrm{ml}$ of hexane with $0.4 \mathrm{ml}$ of $2 \mathrm{~N}$ methanolic potassium hydroxide, and analysed using a Hewlett-Packard HP 4890D (Hewlett-Packard Company, Wilmington, DE) chromatograph equipped with a capillary column (Supelcowax: $30 \mathrm{~m} \times 0.53 \mathrm{~mm} ; 0.25$ $\mu \mathrm{m})$, a splitless injector and a flame ionization detector (FID). The carrier gas was nitrogen, with a flow rate of $1 \mathrm{ml} \mathrm{min}{ }^{-1}$. The temperatures of the injector, the detector and the oven were held at 220,250 and $210^{\circ} \mathrm{C}$, respectively. The injection volume was $1 \mu \mathrm{l}$.

\subsection{Pigment content}

Chlorophyll and carotenoid contents were determined colorimetrically as previously described (Minguez-Mosquera et al., 1991). The maximum absorption at $670 \mathrm{~nm}$ is related to the chlorophyll fraction, while the maximum absorption at $470 \mathrm{~nm}$ is related to the carotenoid fraction. The values of the coefficients of specific extinction applied were E0 $=613$ for pheophytin, a major component in the chlorophyll fraction, and E0 = 2000 for lutein, a major component in the carotenoid fraction. Thus, the pigment contents were calculated as follows:

$$
\begin{aligned}
& \text { Chlorophyll }\left(\mathrm{mg} \mathrm{kg}^{-1}\right)=\left(\mathrm{A}_{670} \times 10^{6}\right) /(613 \times 100 \times \mathrm{d}) \\
& \text { Carotenoid }\left(\mathrm{mg} \mathrm{kg}^{-1}\right)=\left(\mathrm{A}_{470} \times 10^{6}\right) /(2000 \times 100 \times \mathrm{d})
\end{aligned}
$$

where $\mathrm{A}$ is the absorbance and $\mathrm{d}$ is the spectrophotometer cell thickness $(1 \mathrm{~cm})$.

\subsection{Total phenolic content}

Total phenol contents were quantified colorimetrically (RANALLi et al., 1999). Phenolic compounds were isolated by triple extraction of a solution of oil $(10 \mathrm{~g})$ in hexane $(20 \mathrm{ml})$ with $30 \mathrm{ml}$ of a methanol water mixture $(60: 40, \mathrm{v} / \mathrm{v})$. The Folin-Ciocalteu reagent (Merck Schuchardt $\mathrm{OHG}$, Hohenbrunn, Germany) was added to a suitable aliquot of the combined extracts, and the absorption of the solution at $725 \mathrm{~nm}$ was measured. Values are given as milligrams of caffeic acid per kilogram of oil (GUTFINGER, 1981).

\subsection{Volatile compound analyses}

Solid phase microextraction was used as a technique for headspace sampling of virgin olive oils. SPME devices coated with polydimethylsiloxane (PDMS, $100 \mu \mathrm{m}$ ) were used for sampling the headspace of $2 \mathrm{ml}$ of olive oil inserted into a $5 \mathrm{ml}$ glass septum vial and allowed to equilibrate for $30 \mathrm{~min}$. After the equilibration time, the fibre was exposed to the headspace for $50 \mathrm{~min}$ at $25^{\circ} \mathrm{C}$ room temperature. Once sampling was finished, the fibre was withdrawn into the needle and transferred to the injection port on the GC-FID and GC-MS system. GCEIMS separations were performed with a Varian CP 3800 gas chromatograph equipped with a DB-5 capillary column $(30 \mathrm{~m} \times 0.25 \mathrm{~mm}$; coating thicknes $=0.25 \mu \mathrm{m})$ and a Varian Saturn 2000 ion trap mass detector.

Analytical conditions were as follows: injector and transfer line temperature at 250 and $240{ }^{\circ} \mathrm{C}$, respectively; oven temperature was programmed from 60 to $240{ }^{\circ} \mathrm{C}$ at $3{ }^{\circ} \mathrm{C} \mathrm{min}^{-1}$; carrier gas, helium at $1 \mathrm{ml} \mathrm{min}{ }^{-1}$; splitless injection. The identification of the constituents was based on comparison of the retention times with those of authentic samples, comparing their 
linear retention indices relative to the series of $n$-hydrocarbons, and on computer matching against commercial (NIST 98 and ADAMS) and home-made library mass spectra built from pure substances and components of known oils and MS literature data (DAVIES, 1990). Moreover, the molecular weights of all the identification substances were confirmed by GCCIMS, using $\mathrm{MeOH}$ as $\mathrm{CI}$ ionising gas.

\subsection{Oil stability}

Oxidative stability was evaluated by the Rancimat method (GuTIÉRREZ, 1989). Stability was expressed as the oxidation induction time $(\mathrm{h})$, measured with the Rancimat 743 apparatus (Metrohm, Herisau, Switzerland), using an oil sample of $3.6 \mathrm{~g}$. The oil temperature was $101.6^{\circ} \mathrm{C}$ and the air flow was $101 \mathrm{~h}^{-1}$.

\subsection{Statistical analysis}

Significant differences between means were determined by an analysis of variance, which applied a Duncan's test. Differences were considered statistically significant when the probability was greater than $99 \%(\mathrm{P}<0.01)$. The statistical analysis was performed using SPSS 13.0 for Windows.

\section{Results and discussion}

\subsection{Fatty acid composition}

Table 1 shows the percentage of major fatty acids. In the samples analysed in this experimentation, the most abundant fatty acid was oleic acid (C18:1) with contents varying from 57.20 to $62.76 \%$. Furthermore, the levels of palmitic $(\mathrm{C} 16: 0)$ and palmitoleic (C16:1) acids ranged from 13.32 to $17.31 \%$ and from 0.33 to $0.62 \%$, respectively. Rain-fed olive oils showed a statistically significant higher content of oleic acid compared to the MSW-irrigated ones. Olive oil samples obtained from suckers in the rain-fed treatment were found to show the higher content in total monounsaturated fatty acids (63\%), due to their high percentage of oleic acid. Olive oil samples obtained from trees from cuttings in rain-fed treatment were found to have higher percentage in polyunsaturated fatty acids (19\%) due to their high content in linoleic acid.

The distribution of fatty acid composition of the oil samples of both treatments covers the normal range expected for VOO. For both treatments, the most abundant acid was the oleic one with values recorded in oil obtained from rain-fed plants statistically higher than those in oil of MSW treated ones. The low oleic level in olive oils from irrigated trees could probably be due to stearoyl-ACP D9 desaturase inhibition by irrigation with MSW. Results are confirmed by the high stearic acid level, whereas olive oils from MSW irrigated trees had higher contents of palmitic, palmitoleic, stearic and linolenic acids. The data of oleic acid content in MSW treatment could be due to triacylglycerols active biosynthesis inhibition by water salinity. Gomez-RICO and co-workers (2007) reported that the increase in oleic acid content is due to the triacylglycerols active biosynthesis, involving a fall in the relative percentage of the oil's palmitic acid content. Rain-fed olive oils showed a statistically significant higher content of linoleic acid as compared to the MSW-irrigated ones. It is due to the transformation of oleic acid into linoleic one by the oleate desaturase activity, which is active during triacylglycerol biosynthesis (SANCHEZ \& HARWOOD, 2002). 
Table 1. Fatty acid composition of virgin olive oil samples from the two methods of olive tree propagation under two treatments (MSW-irrigated plot and rain-fed one)

\begin{tabular}{|c|c|c|c|c|}
\hline & \multicolumn{2}{|c|}{ Olives from cuttings } & \multicolumn{2}{|c|}{ Olives from suckers } \\
\hline & Rain-fed & MSW irrigated & Rain-fed & MSW irrigated \\
\hline Palmitic acid (C16:0) & $13.32 \pm 0.11 \mathrm{a}$ & $15.35 \pm 0.10 \mathrm{~b}$ & $16.50 \pm 0.12 b$ & $17.31 \pm 0.10 \mathrm{c}$ \\
\hline Palmitoleic acid (C16:1) & $0.33 \pm 0.08 \mathrm{a}$ & $0.42 \pm 0.07 \mathrm{a}$ & $0.53 \pm 0.01 b$ & $0.62 \pm 0.02 \mathrm{c}$ \\
\hline Stearic acid (C18:0) & $2.26 \pm 0.16 \mathrm{a}$ & $2.53 \pm 0.13 b$ & $3.15 \pm 0.15 \mathrm{c}$ & $3.55 \pm 0.12 \mathrm{~d}$ \\
\hline Oleic acid (C18:1) & $60.16 \pm 1.28 b$ & $57.20 \pm 0.30 \mathrm{a}$ & $62.76 \pm 0.41 \mathrm{c}$ & $60.65 \pm 0.42 b$ \\
\hline Linoleic acid (C18:2) & $18.64 \pm 0.69 \mathrm{~d}$ & $17.32 \pm 0.1 \mathrm{c}$ & $15.0 \pm 0.22 \mathrm{~b}$ & $14.32 \pm 0.22 \mathrm{a}$ \\
\hline Linolenic acid (C18:3) & $0.66 \pm 0.09 \mathrm{~b}$ & $0.72 \pm 0.08 \mathrm{c}$ & $0.57 \pm 0.14 \mathrm{a}$ & $0.78 \pm 0.12 \mathrm{c}$ \\
\hline Arachidic acid (C20:0) & $0.42 \pm 0.02 b$ & $0.48 \pm 0.11 \mathrm{c}$ & $0.35 \pm 0.04 b$ & $0.47 \pm 0.12 \mathrm{a}$ \\
\hline $\begin{array}{l}\text { Saturated fatty acids } \\
\text { (SFAs) }\end{array}$ & $16 \pm 0.29 \mathrm{a}$ & $18.36 \pm 0.13 b$ & $20 \pm 0.12 c$ & $21.33 \pm 0.11 \mathrm{~d}$ \\
\hline $\begin{array}{l}\text { Monounsaturated fatty } \\
\text { acids (MUFAs) }\end{array}$ & $60.49 \pm 0.12 b$ & $57.62 \pm 0.30 \mathrm{a}$ & $63.29 \pm 0.13 \mathrm{~d}$ & $61.27 \pm 0.34 \mathrm{c}$ \\
\hline $\begin{array}{l}\text { Polyunsaturated fatty } \\
\text { acids (PUFAs) }\end{array}$ & $19.3 \pm 0.22 \mathrm{c}$ & $18.04 \pm 0.15 b$ & $15.57 \pm 0.13 \mathrm{a}$ & $15.1 \pm 0.12 \mathrm{a}$ \\
\hline
\end{tabular}

Mean \pm S.D. $(n=6)$. Significant differences within the same row are shown by different letters $(\mathrm{P}<0.01)$.

A higher percentage of polyunsaturated fatty acids was reported at rain-fed conditions as compared to MSW-irrigated treatment. The higher percentage of PUFAs can affect the olive oil quality by giving rise to oxidation shortening the shelf-life of the oil. The unsaturated fatty acid content was lower in MSW as compared to a control treatment. The lowest unsaturated fatty acid percentage is linked to acceleration of maturation by salinity. ELAgaimy and co-workers (1994), focusing on olive oil composition under different saline water levels, have shown that oleic acid percentage displayed a slight increase under irrigation with saline water in comparison to the control treatment. The slight increase of oleic acid content recorded under saline irrigation treatment has been also noted by WIESMAN and coworkers (2004).

\subsection{Oil quality parameters and pigment contents}

Free acidity ranging from 0.6 to $0.8 \%$ and peroxide value ranging from 14.5 to $17.2 \mathrm{meq}$ of $\mathrm{O}_{2} \mathrm{~kg}^{-1}$ of the different olive oil samples were considerably lower than the upper limit of $0.8 \%$ as oleic acid and 20 meq $\mathrm{O}_{2} \mathrm{~kg}^{-1}$ as the peroxide value established by EU legislation for extra virgin olive oil (Table 2). Moreover, these two quality indices were not influenced by the MSW irrigation, as no statistically significant differences were observed between both treatments $(\mathrm{P}>0.05)$.

Our results show that the origin of the tree and MSW irrigation had little influence on the analytical parameters (free fatty acid content, peroxide value and extinction coefficients at 232 and $270 \mathrm{~nm}$ ), which are affected by factors causing damage to the fruit (e.g. olive fly attacks or improper systems of harvesting, transport and storage of olives) (KIRITSAKIs et al., 1998). 
Table 2. Quality parameters of Chemlali olive oil samples from the two methods of olive tree propagation under two treatments (MSW-irrigated plot and rain-fed one)

\begin{tabular}{|c|c|c|c|c|}
\hline & \multicolumn{2}{|c|}{ Olives from cuttings } & \multicolumn{2}{|c|}{ Olives from suckers } \\
\hline & Rain-fed & MSW irrigated & Rain-fed & MSW irrigated \\
\hline Acidity (\%, as oleic acid) & $0.8 \pm 0.1 b$ & $0.79 \pm 0.03 \mathrm{~b}$ & $0.64 \pm 0.03 \mathrm{a}$ & $0.60 \pm 0.02 \mathrm{a}$ \\
\hline $\mathrm{PV}\left(\right.$ meq $\mathrm{O}_{2} \mathrm{~kg}^{-1}$ ) & $16.8 \pm 1 \mathrm{~b}$ & $17.2 \pm 0.3 b$ & $14.5 \pm 0.58 \mathrm{a}$ & $14.7 \pm 0.8 \mathrm{a}$ \\
\hline $\mathrm{K}_{270}$ & $0.08 \pm 0.01 \mathrm{a}$ & $0.07 \pm 0.02 \mathrm{a}$ & $0.07 \pm 0.08 \mathrm{a}$ & $0.06 \pm 0.03 \mathrm{a}$ \\
\hline $\mathrm{K}_{232}$ & $0.55 \pm 0.18 \mathrm{a}$ & $0.52 \pm 0.13 \mathrm{a}$ & $1.20 \pm 0.09 \mathrm{~b}$ & $1 \pm 0.12 \mathrm{~b}$ \\
\hline Oxidative stability (h) & $45.7 \pm 2.30 \mathrm{a}$ & $50 \pm 2.03 b$ & $53.2 \pm 1.80 \mathrm{c}$ & $58 \pm 1.5 \mathrm{~d}$ \\
\hline Chlorophylls (mg kg-1) & $2.15 \pm 0.25 b$ & $1.5 \pm 0.23 \mathrm{a}$ & $2.81 \pm 0.15 \mathrm{c}$ & $1.9 \pm 0.13 \mathrm{a}$ \\
\hline Carotenoids ( $\mathrm{mg} \mathrm{kg}^{-1}$ ) & $1.14 \pm 0.22 \mathrm{c}$ & $0.8 \pm 0.22 \mathrm{a}$ & $1.8 \pm 0.19 \mathrm{~d}$ & $1.0 \pm 0.13 \mathrm{~b}$ \\
\hline Phenols ( $\mathrm{mg} \mathrm{kg}^{-1}$ ) & $700 \pm 13.5 \mathrm{a}$ & $725 \pm 13 b$ & $810 \pm 9.5 \mathrm{c}$ & $860 \pm 12 d$ \\
\hline
\end{tabular}

Mean \pm S.D. $(n=6)$. Significant differences within the same row are shown by different letters $(P<0.001)$. PV: peroxide value; $\mathrm{K}_{232}$ and $\mathrm{K}_{270}$ : values of specific extinction, are given as absorbance at 232 and $270 \mathrm{~nm}$, respectively

Oils from suckers had a higher content of chlorophyll and carotenoids. Chlorophyll contents ranged from 1.5 to $2.8 \mathrm{mg} \mathrm{kg}^{-1}$. Chlorophyll and carotenoid contents in the oil samples were significantly affected by irrigation. Indeed, amounts of chlorophylls and carotenoids decreased in oils when the water supplied increased. The total pigment content in olive oil is an important parameter for evaluating olive oil quality. Furthermore, pigments are involved in auto-oxidation and photo-oxidation mechanisms (GuTIÉRREZ, 1989).

\subsection{Changes in the oxidative stability}

A significant difference of oxidative stability was reported between the treatments (Table 2), more stable oil being obtained from trees from suckers $(58 \mathrm{~h})$ from the MSW irrigated treatment. Olive oil samples obtained from fruit of trees from suckers were found to have the higher content in total phenols from both treatments. These differences in phenol concentration in the oils could be a consequence of the different water and salinity stress levels of olive from rain-fed and irrigated conditions that involve changes in the activity of enzymes responsible for phenolic compound synthesis, as L-phenylalanine ammonia-lyase activity is higher under irrigated conditions (PATUMI et al., 1999).

\subsection{Volatile compounds analyses}

Volatile aroma compounds of the different samples are reported in Table 3. Fifteen compounds have been characterised by GC-FID and GC-MS analysis. (E)-2-Hexenal was the major constituent, accounting for about $55 \%$ of the whole volatiles. Other compounds present in relatively high concentrations were hexanal $(2.7-4.8 \%),(E, Z)-2,4$-heptadienal $(9.2-11.8 \%)$, $(E)$ - $\beta$-ocimene $(0.5-1)$, nonanal $(0.6 \%)$, and $(E, E)$ - $\alpha$-farnesene $(0.5-2.4 \%)$. No substantial differences in the volatile aroma compounds of the different samples were noticed which could be related to the irrigation conditions and to the water salinity. The chemical composition of the volatile fraction of Chemlali olive oils was quite variable, depending on the method used for olive tree propagation. The volatile fraction of the oil from trees from cuttings was 
characterised by the pre-eminence of two compounds: $(E, Z)$-2,4-heptadienal $(9.2 \%)$ and $(E)$ 2-hexenal (59-60.2\%). The volatile fraction of the oil from suckers was characterised by the pre-eminence of two compounds: (E)-2-hexenal (66.2-67.2\%) and (E,Z)-2,4-heptadienal $(11.5-11.8 \%)$. Differences in the levels of aldehydes in olive oil samples were not clearly observed between the methods adopted for olive tree propagation and between the two treatments. Moreover, in oils from the two methods of olive tree propagation differences were found in the content of $(E, E)-\alpha$-farnesene.

Table 3. Composition of the volatile fraction (\%) obtained from Chemlali virgin olive oils extracted by HS-SPME from the two treatments (MSW-irrigated plot and rain-fed one)

\begin{tabular}{|c|c|c|c|c|c|}
\hline & \multirow[t]{2}{*}{ LRI } & \multicolumn{2}{|c|}{ Olives from cuttings } & \multicolumn{2}{|c|}{ Olives from suckers } \\
\hline & & Rain-fed & MSW irrigated & Rain-fed & MSW irrigated \\
\hline Hexanal & 800 & $4.8 \mathrm{~b}$ & $4.2 \mathrm{~b}$ & $2.7 \mathrm{a}$ & $2.8 \mathrm{a}$ \\
\hline (E)-2-hexenal & 851 & $59.8 \mathrm{a}$ & $60.2 \mathrm{~d}$ & $66.2 b$ & $67.2 \mathrm{c}$ \\
\hline 1-Hexanol & 871 & - & & $5.5 \mathrm{a}$ & 5.4 \\
\hline$(E, Z)$-2,4-heptadienal & 998 & $9.2 \mathrm{a}$ & $9,1 \mathrm{a}$ & $11.5 b$ & $11.8 \mathrm{~b}$ \\
\hline (E)- $\beta$-ocimene & 1051 & $1 \mathrm{~b}$ & $1 \mathrm{~b}$ & $0.7 \mathrm{a}$ & $0.5 \mathrm{a}$ \\
\hline Nonanal & 1104 & $0.7 \mathrm{a}$ & $0.6 \mathrm{a}$ & $0.7 \mathrm{a}$ & $0.7 \mathrm{a}$ \\
\hline Decanal & 1206 & $7.5 \mathrm{~b}$ & $8.6 \mathrm{c}$ & $4.9 \mathrm{a}$ & $4.9 \mathrm{a}$ \\
\hline Tridecane & 1300 & $3.9 \mathrm{a}$ & $2.6 \mathrm{a}$ & - & - \\
\hline$\alpha$-Copaene & 1377 & $0.2 \mathrm{a}$ & $0.2 \mathrm{a}$ & - & - \\
\hline Isocaryophyllene & 1407 & $1.1 \mathrm{a}$ & $1.4 \mathrm{a}$ & $0.5 \mathrm{a}$ & $0.6 \mathrm{a}$ \\
\hline$\beta$-Caryophyllene & 1418 & $2.5 \mathrm{~b}$ & $2.5 \mathrm{~b}$ & $1.3 \mathrm{a}$ & $1.4 \mathrm{a}$ \\
\hline Dihydro- $\beta$-ionone & 1435 & $0.1 \mathrm{a}$ & $0.3 \mathrm{a}$ & - & - \\
\hline$\alpha$-Humulene & 1456 & $1.3 \mathrm{~b}$ & $1.4 \mathrm{~b}$ & $0.7 \mathrm{a}$ & $0.6 \mathrm{a}$ \\
\hline$(E, E)$ - $\alpha$-farnesene & 1505 & $2.1 \mathrm{~b}$ & $2.4 \mathrm{~b}$ & $0.6 \mathrm{a}$ & $0.5 \mathrm{a}$ \\
\hline Cedrol & 1597 & $0.7 \mathrm{a}$ & $0.6 \mathrm{a}$ & $0.2 \mathrm{a}$ & $0.3 \mathrm{a}$ \\
\hline Total identified & & 94.9 & 95.2 & 95.2 & 95.8 \\
\hline
\end{tabular}

$\mathrm{RI}$ : retention indices; data values expressed in $\mathrm{mg} \mathrm{kg}^{-1}$. Mean $\pm \mathrm{SD}(\mathrm{n}=3)$, significant differences within the same row are shown by different letters $(\mathrm{P}<0.005)$; - : compound not detected

(E)-2-hexenal was the principal volatile identified in the oils from the two ways of olive tree propagation and the two irrigation treatment. $(E)$-2-hexenal was also the main volatile reported among constituents of olive oil aroma (VicHi et al., 2003; Ben TEMIME et al., 2006). From the levels of the esters in the olive oil samples it can be hypothesised that levels of alcohol acetyl transferase (AAT) are not dependent on the origin of the olive tree and MSW irrigation. However, some differences in the levels of some terpene hydrocarbons were observed in our olive oil samples. The hydrocarbons of olive oil have been studied by different authors as possible markers to distinguish virgin olive oil from different olive varieties or geographical origins (APARICIO and LUNA, 2002; VICHI et al., 2003). 


\section{Conclusions}

Olive oil samples for the two methods of olive tree propagation were defined as belonging to the commercial class of extra virgin olive oil. On the other hand, it seems that irrigation influenced fatty acid composition, phenol, chlorophyll and carotenoid contents. Irrigation with MSW had a positive effect on "Chemlali" olive oil quality as compared to rain-fed conditions, by its moderate monounsaturated fatty acids and low content of polyunsaturated ones responsible for its high stability; on the other hand, there was a significant increase of phenol contents and an increase of the oxidative stability of the MSW-irrigated samples. However, our results showed that olive oil quality was different when the olive tree is from suckers or cuttings. Oils obtained from fruit of trees from suckers showed high levels of antioxidants compared to oils from trees from cuttings, with an increased oxidative stability and high level of oleic acid in response to moderate saline water irrigation.

\section{References}

Aparicio, R. \& Luna, G. (2002): Characterisation of monovarietal virgin olive oils. Eur. J. Lipid Sci. Technol., 104, 614-627.

Baccouri, B., Ben Temime, S., Taamalli, W., Daoud, D., Msallem, M. \& Zarrouk, M. (2007): Analytical characteristics of virgin olive oils from two new varieties obtained by controlled crossing on Meski variety. J. Fd. Lipids, 14, 19-34.

Ben Temime, S., Campeol, E., Cioni, P.L., Daoud, D. \& Zarrouk, M. (2006): Volatile compounds from Chétoui olive oil and variations induced by growing area. Fd Chem., 99, 315-325.

BouAzIz, A. (1990): Behaviour of some olive varieties irrigated with brackish water and grown intensively in the central part of Tunisia. Acta Hortic., 286, 247-250.

DAVIES, N.W. (1990): Gas chromatographic retention indexes of monoterpenes and sesquiterpenes on methyl silicone and Carbowax 20M phases. J. Chromatog., 503, 1-24.

El-Agaimy, M.A., Neff, W.E., El-Sayed, M. Awatif, I.I. (1994): Effect of saline irrigation water on olive oil composition. J. Am. Oil Chem. Soc., 71, 1287-1289.

Gomez-Rico, A., Salvador, M.D., Moriana, A., Perez, D., Olmedilla, N., Ribas, F. \& Fregapane, G. (2007): Influence of different irrigation strategies in a traditional Cornicabra cv. olive orchard on virgin olive oil composition and quality. Fd Chem., 100, 568-578.

Gutfinger, T. (1981): Polyphenols in olive oil. J. Am. Oil Chem. Soc., 58, 966-968.

Gutiérrez, F. (1989): Determinación de la estabilidad oxidativa de aceites de oliva vírgens. Comparación entre el método del oxígeno activo (AOM) y el método Rancimat (Determination of the oxidative stability of virgin olive oils. Comparison between AOM and Rancimat methods.) Grasas Aceites, 40, 1-4.

Kiritsakis, A.K., Nauos, G.D., Polymenoupoulos, Z., Thomai, T. \& Sfakiotakis, E.Y. (1998): Effect of fruit storage conditions on olive oil quality. J. Am. Oil Chem. Soc., 75, 721-724.

Minguez-Mosquera, M.I., Rejano-Navarro, L., Gandulrojas, B., Sanchez Gomez, A.H. \& Garrido-Fernandez, J. (1991): Color-pigment correlation in virgin olive oil. J. Am. Oil Chem. Soc., 86, 332-336.

Patumi, M., D’Andria, R., Fontanaza, G., Morelli, G., Gioro, P. \& Sorrentino, G. (1999): Yield and oil quality of intensively trained trees of three cultivars of olive (Olea europaea L.) under different irrigation regimes. J. Hortic. Sci. Biotechnol., 74, 729-737.

Patumi, M., D’Andria, R., Marsilio, V., Fontanazza, G., Morelli, G. \& Lanza, B. (2002): Olive and olive oil quality after intensive monocone olive growing (Olea europaea L., cv. Kalamata) in different irrigation regimes. Fd Chem., 77, 27-34.

Ranalli, A., De Mattia, G., Patumi, M. \& Proietti, P. (1999): Quality of virgin olive oil as influenced by origin area. Grasas Aceites, 50, 249-259.

Rattan, R.K., Data, S.P., Chhonkar, P.K., Suribabu, K. \& Singh, A.K. (2005): Long term impact of irrigation with sewage effluents on heavy metal content in soil, crops and groundwater - a case study. Agric. Ecosyst. Environ., 109, 310-322. 
Salvador, M.D., Aranda, F., Gómez-Alonso, S. \& Fregapane, G. (2001): Cornicabra virgin olive oil: A study of five crop seasons. Composition, quality and oxidative stability. Fd Chem., 74, 267-274.

Sanchez, J. \& Harwood, J.L. (2002): Biosynthesis of triacylglycerols and volatiles in olives. Eur. J. Lipid Sci. Technol., 104, 564-573.

Vichi, S., Pizzale, L., Conte, L.S., Buxaderas, S. \& López-Tamames, E. (2003): Solid phase microextraction in the analysis of virgin olive oil volatiles fraction: Characterisation of virgin olive oils from two distinct geographical areas of northern Italy. J. Agric. Fd Chem., 57, 6572-6577.

Wiesman, Z., ItzhaK, D. \& Ben Dom, N. (2004): Optimization of saline water level for sustainable Barnea olive and oil production in desert conditions. Sci. Horticult., 100, 257-266. 